\title{
'n Prinsipiële diskoers oor die epistemologiese fundering van die Pastorale Teologie: 'n Oproep tot reformasie
}

Author:

Johan Janse van Rensburg ${ }^{1}$

Affiliation:

${ }^{1}$ Faculty of Theology, University of the Free State, Bloemfontein, South Africa

Correspondence to: Johan Janse van Rensburg

Email:

jjvanr@yebo.co.za

Postal address:

PO Box 26067,

Langenhovenpark 9300,

South Africa

\section{Dates:}

Received: 22 Aug. 2015

Accepted: 28 Jan. 2015

Published: 30 Mar. 2015

How to cite this article: Janse van Rensburg, J., 2015, "n Prinsipiële diskoers oor die epistemologiese fundering van die Pastorale Teologie: 'n Oproep tot reformasie', In die Skriflig 49(3), Art. \#1877, 10 pages. http://dx.doi.org/10.4102/ ids.v49i3.1877

\section{Copyright:}

(C) 2015. The Authors.

Licensee: AOSIS

OpenJournals. This work is licensed under the Creative Commons Attribution License.

Read online:
Hierdie artikel is as 'n huldeblyk aan prof. George Lotter by sy aftrede geskryf en uit erkenning vir sy bydrae tot die wetenskapsbeoefening van die Praktiese Teologie. Die artikel ondersoek die huidige konteks van die pastorale teologie. Aangesien epistemologiese keuses die metodiek en uitkoms van die pastoraat bepaal, is daar 'n dringende noodsaak om die epistemologiese invloede op die pastorale teologie te evalueer. Die artikel fokus op die epistemologiese dinamika wat die pastoraat verander het van 'n skriftuurlike fundering na 'n kommunikatiewe handelingsteoretiese en postmoderne narratiewe strategie. Die navorsingsvraag is: Is ' $n$ reformatoriese terugkeer na 'n bybels-gefundeerde pastoraat teen die agtergrond van die epistemologiese invloede nog moontlik?

As a tribute to Prof. George Lotter on the occasion of his retirement and to his contribution to practical theology, this article focuses on the current situation of pastoral theology worldwide but mostly in South Africa. Since epistemological choices determine the method and content of research on pastoral theology, as well as the practical implementation thereof, there is an urgent need to evaluate the influences on pastoral theology and the results of these influences. The article focuses on the epistemological dynamics that have changed pastoral theology from a scriptural approach to a discipline of communicative acts and a postmodern strategy of narrative pastoral counselling. The research question is: Is it still possible to have a reformed pastoral theology and pastoral counselling against the backdrop of these epistemological changes?

\section{Inleiding}

Dit is 'n groot voorreg om as 'n huldeblyk aan prof. George Lötter by geleentheid van sy aftrede aan hierdie publikasie mee te werk. Die jarelange kollegialiteit en die wete dat ons teologies dieselfde vertrekpunte gehad het, het ons vriendskap en samewerking versterk. Ek is opregte dank aan hom verskuldig omdat hy my voortdurend by die eksaminering en evaluering van artikels en die aanbied van lesings betrek het. Sy eie akademiese aktiwiteite kan as verbysterend beskryf word. Die aantal doktorale en meestersgraadstudente wat hy tot 'n suksesvolle einde begelei het, is verstommend. Sy gepubliseerde artikels was deeglik en deurgaans getrou aan die epistemologiese vertrekpunte wat ek en hy deel. Dit is gepas om hierdie artikel oor 'n reformatoriese pastoraat aan hom op te dra, aangesien hy in sy akademiese dissipline nooit sy reformatoriese wortels prysgegee het nie.

\section{Oor paradigma en epistemologie}

Dit is 'n algemeen bekende en aanvaarde feit dat die paradigmaverskuiwing van Modernisme na Postmodernisme elke aspek en faset van die wetenskapsbeoefening beïnvloed het (Seidman 1994:1-23). Ook die teologie in die algemeen en die pastorale teologie in die besonder het nie aan hierdie magtige suigkrag ontkom nie (Janse van Rensburg 2000a:36-63; 2000b:36-63). Louw (1997:118) toon aan dat die paradigmaskuif die pastoraat van 'n dogmaties-georiënteerde verklarende vertrekpunt (die prominentste verteenwoordig deur die teodisee-benadering) na 'n hermeneutiese verstaans model verskuif het. Vanweë hierdie verskuiwing waarsku Louw dat die teologiese karakter van die pastoraat en pastorale terapie in die gedrang is en nie verraai moet word nie.

Hierdie fundamentele wysiging in benaderingswyse het verreikende konsekwensies vir die pastorale teologie gehad. Die belangrikste konsekwensie van die paradigmaskuif was waarskynlik dat die objek-subjekbenadering in ' $n$ intersubjektiewe of hermeneutiese benadering verander 
is. Terloops, hierin lê een van die vele teenstrydighede van die Postmodernisme verskuil. Enersyds val die klem in 'n postmoderne ontleding op die belang van die individu met sy veelheid van narratiewe en 'n subjektiewe waarheidsbeskouing. Die kliënt is in die terapeutiese konteks die 'ekspert' (Anderson \& Goolishian 1992) terwyl die pastor 'n 'niewetende posisie' inneem, om deur dekonstruksie nuwe moontlikhede oop te breek (E. Kotzé \& D. Kotzé 1997:42; Roux \& Kotzé 1997:65-66). Andersyds verteenwoordig 'die dood van die subjek' ('n tipiese postmoderne uitdrukking) juis die onvoorwaardelike relativering van die individuele perspektivisme (Janse van Rensburg 2000b:13-15). Selfs die denke van filosowe soos Heidegger en Nietzsche word deur Rorty gerelativeer: 'They are only perspectives', skryf Rorty (1989:120).

In hierdie bydrae word die implikasies van so 'n koersverandering ondersoek ten einde die vraag te beantwoord of daar ruimte vir 'n oproep van Semper reformanda is.

\section{Sentrale navorsingsvraag}

Die Postmodernisme is veral vir die absolute relativisme bekend wat aan die wortel van hierdie ideologie groei. Gegewe die aard van die Postmodernisme, die radikale verskuiwings wat dit meegebring het en die toenemende gewildheid daarvan, ontstaan die vraag of daar nog genoeg oorblyfsels van 'n gereformeerde en pastorale teologie is om van 'n reformatoriese pastoraat te kan praat. Is 'n reformatoriese pastoraat enigsins versoenbaar met 'n postmoderne epistemologie? Kan die geweldige suigkrag van die Postmodernisme ontkom word om weer na 'n bybels-gefundeerde pastoraat en pastorale terapie terug te keer?

\section{Metodologie}

In die eerste deel van die artikel word 'n oorsigtelike bespreking van die pastorale ontwikkeling aangebied ten einde die effek van die paradigmaskuif daarteen te profileer. Dit is natuurlik onmoontlik om 'n sinopsis van al die pastorale modelle en benaderings weer te gee. Slegs 'n geselekteerde deel wat die navorsingsvraag pertinent bedien, word aan die orde gestel. Op grond van hierdie oorsig word 'n kodering van merkers gedoen wat as essensiële eienskappe van 'n reformatoriese pastorale benadering beskou kan word.

Volgens Johnson en Christensen (2008:413) is kodering die eerste fase van 'n proses om 'n basisteorie vanuit kwalitatiewe gegewens te ontwikkel. In hierdie artikel word nie van kwalitatiewe gegewens gebruik gemaak nie, maar van epistemologiese vertrekpunte vir die pastoraat. Die proses van kodering word ook as 'n 'van onder'benadering beskryf. Persoonlike oortuigings (in hierdie artikel deur epistemologiese vertrekpunte gereflekteer) word as vertrekpunt gebruik om 'n nuwe basisteorie te formuleer (Pieterse 2010:113-129)
In die derde afdeling word die navorsingsvraag hieruit beantwoord, naamlik of ' $n$ oproep tot ' $n$ reformatoriese pastoraat legitiem is.

\section{Van waar na waar? ${ }^{1}$}

'n Kursoriese blik oor die pastorale teologie herinner 'n mens aan die verskillende benaderings vir die pastoraat wat in die verlede oorheers het: die ampte (Heyns \& Jonker 1977:297), die koninkryk (Bolkestein 1964), die pneumatologie (Rebel 1981) en 'n pleidooi vir die verbond (De Klerk 1985:23-39; Janse van Rensburg 1996). Lotter (2001:317-329) bespreek die reformatoriese impak van Jay E. Adams se noutetiese model en toon aan dat hierdie benadering die rug op 'n sielkundegedomineerde pastoraat gekeer het. As sodanig was dit die begin van ' $n$ reformatoriese proses om na die Skrif en die Reformasie terug te keer. In al hierdie benaderings het ' $n$ ander proprium gefunksioneer, maar dit was deurgaans 'n teologiese vertrekpunt wat by 'n bybelse teologie wou bly. In hierdie verband sou ons dus nog van 'n reformatoriese pastoraat en pastorale teologie kon praat.

Daniël Louw se konvergensiemodel (1997) kon daarin slaag om die voorafgaande benaderings in 'n skrifgefundeerde ontmoetingsgebeure te laat saamvloei. Deur middel van bybelse grondmotiewe soos eskatologie, verbond, koninkryk, Christologie en pneumatologie was sy benadering as reformatoriese model vir die pastoraat rigtinggewend.

Die verskuiwing van 'n diakoniologiese na 'n praktiesteologiese epistemologie was egter die begin van 'n betekenisvolle verandering in hierdie benadering. Heyns en Jonker (1977:60-77) neem nog die saak op vir 'n diakoniologiese (diens van die Woord) epistemologie teenoor 'n prakties-teologiese benadering. By Firet (1977:126-154) was die leitmotif nog steeds die koninkryk, met die omskrywing van praktiese teologie as die teologiese teorie aangaande die handelingsisteme wat die koms van God tot die mens in sy wêreld intermediêrend dien. Dit is betekenisvol dat Firet (1986:xi) sy teologiese vertrekpunte in die voorwoord van 'n heruitgawe in 1986 herbevestig het. Teologie is vir hom die verkillende handelings om kennis van God te verkry en sy wil te doen. Dit word met funksies van die geloofsgemeenskap aangevul. Daarmee wou Firet die teologiese sowel as die wetenskaplike karakter van die praktiese teologie handhaaf. Tog meen Heitink (1993:120-121) dat selfs Firet nie aan die suigkrag van die paradigmaskuif ontkom het nie.

Onder die invloed van Habermas (Raath 1998:135; Seidman 1994:192) en Ricoeur (1978:98-101) se kommunikatiewe handelingsteorie was die afskeid van 'n bybelse vertrekpunt onafwendbaar. By Ricoeur impliseer die voortgesette interpretasie van die teks in elke sosiale konteks die afskeid van die outeur se bedoeling ('the death of the author'; Heitink 1993:140; Reagen 1973:210-211). In die epistemologiese diskoers tussen diakoniologie en die praktiese teologie het Louw (1993a; 1993b; 1997; 1998)

1.Om die geskiedenis van die pastorale teologie na te vors, is dit onafwendbaar dat gedateerde bronne vir hierdie afdeling gebruik word. 
dikwels met sterkbewoorde waarskuwings betoog dat die prakties-teologiese epistemologie die gevaar loop om sy teologiese karakter te verloor en in die menswetenskappe op te gaan. Intussen het hierdie soms heftige diskoers gaandeweg verflou en het die benaming diakoniologie heeltemal van die toneel verdwyn.

Verskeie ander prakties-teologiese epistemologieë het na vore gekom. Eers was dit Heitink se waardevolle bipolariteitsbeginsel. God en mens, openbaring en ervaring, staan in ' $n$ bipolêre spanning tot mekaar, terwyl die teorie nie voorrang bo die praksis het nie en die praksis ook nie oor die teorie mag heers nie. Teorie word deur die praksis gekorrigeer en omgekeerd (Heitink 1993:148-150). Die kommunikatiewe handelinge staan by Heitink in diens van die evangelie en nie soos by Thurneysen se kerugmatiese model nie, maar eerder as pastorale ontmoetingsgebeure waarin die Woord in die konteks gekommunikeer word. Hoewel die menslike ervaring en die kommunikatiewe handelings die openbaring voorafgaan, erken Heitink (1993:21) nogtans dat die openbaring die menslike ervaring teoreties voorafgaan. Sodoende bly die 'praxis Gottes' sy uitgangspunt in die pastorale teologie en speel die Skrif in hierdie pastorale benadering tóg 'n belangrike rol.

Dit was ongelukkig nie altyd waar omtrent alle pastorale teologie vanuit die prakties-teologiese epistemologie nie. Eensydige klem op die kommunikatiewe handelings het tot ' $n$ indirekte benadering tot Skrifgebruik gelei sodat die Skrif in die pastorale konteks onafwendbaar in onbruik geraak het (Janse van Rensburg 2004:36-37). Daarna het die hermeneutiese benadering in gewildheid toegeneem. Tans word die toneel deur die epistemologie oorheers wat Osmer (2008:4-29) voorstel. Met sy publikasie help hy gemeetelike leiers om probleme te hanteer deur vier vrae te vra: Wat gebeur in 'n bepaalde konteks?; Waarom gebeur dit?; Wat behoort te gebeur? en Wat kan die pastor doen om die situasie te verander? Hoewel dit 'n goeie en bruikbare benadering vir die praktiese teologie en die pastoraat is en myns insiens selfs raakpunte met die benadering van Zerfass het, is dit vreemd dat hierdie model nou skynbaar die sjibbolet van die praktiese teologie gemaak word.

Die kursoriese uiteensetting hierbo maak dit reeds duidelik dat die pastorale toneel radikaal verander het. Die postmoderne ideologie het die pastorale teologie nog verder en meer radikaal oorheers. Dit het die God/mens-interaksie van die pastoraat tot ' $n$ intermenslike gebeure gereduseer. Omdat daar volgens die ideologie van die Postmodernisme geen absolute waarheid is nie, kan God ook nie in so 'n pastorale benadering absoluut wees nie. Al wat oorbly, is intermenslike verhoudings.

So 'n verhorisontalisering van die pastoraat word presies deur Meylahn (2010) se analise van die paradigmaskuif geillustreer, wat hy as 'n werklikheid 'in transito' beskryf. In ooreenstemming met die postmoderne relativering van waarheid redeneer hy dat daar nie waarheid in die vorm van 'grand narratives' is nie, maar slegs gefragmenteerde waarheid en dus 'n veelheid van narratiewe (epistemologieë). Die Skrif se grand narrative moet gedekonstrueer word sodat die ware self, die ontblote self, aan die orde gestel kan word. Die Genesisverhaal word deur middel van dekonstruksie verstaan as 'n proses om die naakte self te ontbloot, die mens gestroop van waarheid, die viering van diversiteit (différence). Wanneer Jesus Christus Homself aanbied as die weg en die waarheid, impliseer dit nie die vestiging van 'n absolute waarheid (Jesus is die verlosser) nie, maar dit word 'n metafoor vir 'n ware lewenswyse - om jou lewe in liefde vir jou naaste op te offer. Hiermee sluit Meylahn (2010) aan by die postmodernis par excellence, Jacque Derrida:

I would like to give this laying down of one's life a Derridian interpretation as 'radical hospitality'. Radical hospitality is to open yourself toward the 'other' to such an extent that the 'self' is destroyed/deconstructed. (p. 8)

Dit kom op 'n kruisiging van wettiese vereistes (vaste waarhede) en 'n bevryding van die self neer om sodoende 'n sosiale band en 'n verloste gemeenskap van 'naked selves' te vorm wat in opofferende liefde vir mekaar verantwoordelikheid aanvaar. Dit is wat Meylahn (2010:1-9) onder ' $\mathrm{n}$ 'holistic pastoral redemptive community' verstaan. Dit is postmoderne dekonstruksie op sy beste.

Absolute relativisme het dit onvanpas gemaak om enigsins rigting of leiding in 'n pastorale gesprek te gee. Die narratiewe benadering, met sy konstruktivistiese en sosiaalkonstruksionistiese epistemologieë het die kliënt (lees: persoon in berading) die kundige (ekspert) gemaak. Pastoraat het in die narratiewe terapie van 'n subjek-objekskema na 'n hermeneutiese of intersubjektiewe skema beweeg. Navorsing in die pastorale teologie het die insigte van die klient betrek, terwyl die objektiewe aard van die pastoraat, wat op die Woord en die waarheid gefokus het, vir die insider-researcher-benadering moes plek maak. Die pastor as kundige oor die Skrif en opgelei om situasies en probleme te evalueer, kon nie langer die gesprek na 'n bepaalde bybelse uitkoms begelei nie. Trouens, volgens sommige outeurs van die narratiewe terapie hoef daar hoegenaamd nie ' $n$ uitkoms te wees nie. Maturana (1985:43) verduidelik byvoorbeeld dat konstruktivisme, die epistemologie wat die narratiewe terapie fundeer, die wil verloor het om mense te verander. Hierdie uitgangspunt is gebaseer op die veronderstelling dat daar nie objektiewe waarheid is nie en dat elke individu in die pastorale gesprek hulle eie konstruk van die werklikheid het. Hierdeur word elke kliënt na hulle eie unieke uitkoms begelei sonder om 'n morele oordeel daaroor uit te spreek of die unieke uitkoms te probeer verander. Dill (1996:213) haal in hierdie verband Gergen aan: 'The constructionist then is not for solutions to issues of good and evil, but rather for increased problemization'.

Die paradigmaskuif in die pastorale teologie kan egter nie slegs tot die Postmodernisme beperk word nie. Daar is ook 'n paradigmaskuif na 'n meer modernistiese verstaan van die pastorale berading wat sterker by wetenskaplike navorsing 
wil aansluit. 'n Voorbeeld hiervan is Bingaman (2013:553556) wat by neuro-teologiese ondersoeke aansluiting soek. Neuro-teologiese ondersoeke poog om die interaksie tussen die breinfunksie en die teologiese (bybelse) beginsels te bepaal. Dit is op sigself nie noodwendig af te wys nie, maar by Bingaman gaan hierdie benadering geheel en al in kontemplatiewe praktyke op wat deur Boeddhiste en die Rooms-Katolieke 'desert Fathers' beoefen word. Hierdie benadering adem 'n meditatiewe spiritualiteit wat nie met 'n reformatoriese spiritualiteit versoenbaar is nie. Die hoogs twyfelagtige 'centering prayer' wat deur die Ontluikende Kerk gewild geword het, is deel van hierdie kontemplatiewe metode om oor teksgedeeltes soos die bergrede te mediteer en mantras daaruit te ontwikkel. Meditasie word belangriker as Skrifwaarhede. Pastorale berading en terapie word hiermee tot selfhelende spiritualiteitspraktyke verhorisontaliseer. Die waarhede van die Skrif word ten koste van mistieke ervarings gerelativeer. Dit is duidelik hoe ver só 'n benadering van 'n reformatoriese pastoraat verwyder is, al word die Skrif op die een of ander manier betrek, nie as ewige waarhede nie, maar as mantras in meditasie.

Uit die voorafgaande is dit duidelik dat teoloë met die narratiewe terapie soos dit hierbo kortliks belig is, van 'n pastorale benadering af wegbeweeg het. Hoewel baie pastorale terapeute wat die narratiewe literatuur en benadering gebruik, nie konsekwent die Woord en gebed wil loslaat nie (Janse van Rensburg 2004:59), speel dit in die praktyk dikwels nie enige rol nie. Trouens, sommige terapeute beskou dit as verraad teen die narratiewe terapie indien die Skrif, morele waardes en gebed in die pastorale terapie betrek word. Dit sou inderdaad ook teenstrydig wees om in 'n postmoderne nie-direktiewe benadering skriftuurlike rigting aan te dui en vaste waarhede te beklemtoon. Navorsing wat met teenstrydige epistemologieë werk, verloor eenvoudig integriteit (Janse van Rensburg 2000a:52-58).

Dit is verbasend en teleurstellend dat Fowler (2012:202) se bespreking van pastorale paradigmas geheel en al die invloed van postmoderne epistemologieë soos dit hierbo kursories bespreek is, verbygaan. Die enigste paradigmaskuif wat hy bespreek, is 'n beweging van 'pastoral counseling' na 'care ministry'. Met laasgenoemde word die gemeentelike pastoraat bedoel.

Bostaande kursoriese beskrywing van die pastorale teologie beteken hoegenaamd nie dat alles sedert die afskeid van 'n diakoniologiese benadering sleg was nie. Inteendeel, dit behoort duidelik te wees dat ' $n$ gekompliseerde en delikate pastorale gesprek van die verskillende benaderings behoort gebruik te maak wanneer een bepaalde benadering of strategie nie by die persoon in berading aanklank vind nie. Juis om hierdie rede behoort die verabsolutering van een model vir die pastoraat vermy te word. Vergelyk in hierdie verband dieselfde uitgangspunt by De Wet en Pieterse (2010:541). De Freitas (2012) stel dit soos volg:

A critically realistic stance enables us to create multiple, complex interactions of continuity versus discontinuity. Science, psychology, philosophy, culture, theology, Scripture, etc. can all be involved in complex interactions that can reveal truth. Inductive and deductive methods, individual and group insight, subjective and objective perspectives, etc. can all contribute to life and knowledge in God. (p. 302)

\section{Wat is ' $\mathrm{n}$ reformatoriese pastoraat?}

In teorie en praktyk is die pastoraat deur die paradigmaskuif sodanig verander (Louw 2003:33-58) dat daar kwalik nog van 'n reformatoriese pastoraat gepraat kan word. Daarom dat die opdrag om oor 'n reformatoriese pastoraat te skryf, so belangrik en tydig is. Maar wat presies sou onder 'n beskrywing van 'n reformatoriese pastoraat kon tuishoort? Die kursoriese oorsig oor die geskiedenis van die pastorale teologie stel die navorser in staat om merkers vir 'n reformatoriese pastoraat te kodeer. Hier word dus nie van 'n definisie van 'n reformatoriese pastoraat gebruik gemaak nie, maar van 'n kodering van geïdentifiseerde merkers.

\section{Skrif en pastoraat}

Die reformatoriese Sola Scriptura veronderstel uitdruklik dat die Skrif op 'n verantwoordelike manier in 'n reformatoriese benadering tot die pastoraat ter sprake behoort te kom. Hier kan vier kategorieë onderskei word, naamlik die afwesigheid van die Skrif; 'n indirekte gebruik van die Skrif; 'n postmoderne Skrifbeskouing; en 'n teologies-verantwoorde gebruik van die Skrif.

'n Oorsig oor die pastorale vakliteratuur reflekteer in die algemeen 'n duidelike afwesigheid van die Skrif in die basisteoretiese fundering. Een so 'n voorbeeld is die kwantitatiewe navorsing om die verhouding tussen spiritualiteit en welsyn (well-being) by adolessente vas te stel (Burnell, Beukes \& Esterhuyse 2009:1-31). Die religieuse invloed op spiritualiteit en welsyn is totaal afwesig terwyl die Skrif geen rol speel nie.

Jossitus (1980) maak 'n doelbewuste keuse vir 'n indirekte Skrifgebruik wat deur middel van 'n praktiserende evangelie van die gemeente in die pastoraat moet figureer. 'n Sprekende voorbeeld van so ' $n$ indirekte Skrifverwysing is Van Knippenberg (2002:154-169) se bespreking van bronne vir spirituele begeleiding ten einde die cura animarum te bewerkstellig. In die artikel is daar 'n vlugtige verwysing na Johannes 10:10, die narratiewe van bybelse en ander geestelike figure, 'n enkele sin oor geloof, hoop en liefde, en die verwysing na die dekaloog. Van Knippenberg sluit aan by die Rooms-Katolieke tradisie om deur meditasie met die Goddelike in aanraking te kom. Die subjek van die cura animarum is die siel self. Hierdie indirekte verwysings na Skrifgegewens toon inhoudelik baie belofte, maar soos dit in die artikel hanteer word, is dit eerder Dante se oortuigings waardeur genesing bewerk moet word, wat aan die woord gestel word.

Selfs waar die Skrif tóg betrek word, is dit nie altyd onproblematies nie. Die gesag waarmee die Skrif spreek en 
die postmoderne epistemologieë staan onafwendbaar en onversoenbaar teenoor mekaar. Die Skrif gaan uit van vaste beginsels terwyl Postmodernisme die relativering van die waarheid as uitgangspunt gebruik. Nogtans wil sommige postmoderne pastorale teoloë nie die gebruik van die Skrif laat vaar nie, maar stel eerder ' $n$ herwaardering van die Skrif aan die orde. Daar is sodoende ' $n$ duidelike ambivalensie by sommige postmoderne pastorale teoloë. Alhoewel Dill (1996) en Joubert (2000) se proefskrifte in die Postmodernisme gefundeer is, kan en wil hulle nie die Skrif loslaat nie. Skrifverwysings kom by Joubert voor, sonder dat die teenstrydigheid van die Skrif met die postmoderne beginsels van relativisme en die verwerping van logosentrisme erken word. Hoewel die Skrif wél betrek word, bly dit niedirektief en dus selektief wanneer etiese normering (bv. homoseksualiteit, egbreuk of konkubinaat) ter sprake kom (Joubert 2000:28-30).

By Jan-Albert van den Berg (2006:164-182) vind 'n mens 'n Skrifbeskouing en -gebruik wat wél nog aanwesig is, maar wat in tipies postmoderne trant gedekonstrueer word. Omdat die taal wat bybelse waarhede verwoord, beperk is, is die teks van die Skrif ook relatief. Van den Berg onderskei tussen die Skrif wat gesaghebbend is en die verskillende interpretasies daarvan. Hy waarsku teen verskillende vertolkings van die Skrif. Word daarmee bedoel dat daar dan tóg net één waarheid van die teks is? Verteenwoordig dit dan nie ontrou aan die postmoderne verwerping van logosentrisme en dus verraad teen die postmoderne epistemologie van sosiale konstruksionisme nie? Van den Berg (2006:175) wil Skrif en konteks in die pastoraat versmelt sodat die mens se verhaal met God se verhaal versoen kan word. Indien taal en waarheid egter voorlopig en dus relatief is, hoe kan dit plaasvind sonder om aan die gekose epistemologie ontrou te wees? (Sien 'n volledige bespreking hiervan by Janse van Rensburg 2007:61-80.)

De Freitas (2012) pak hierdie gekompliseerde tema in sy proefskrif aan. Die probleemstelling wat hy as navorsingsdoelwit stel, is om te bepaal watter rol die Skrif in die konteks van epistemologiese verskille in die pastorale konteks kan speel. Die verhouding tussen bybelse en buitebybelse bronne word hierdeur betrek. $\mathrm{Na}$ 'n lang en deeglike uiteensetting kom hy tot ' $n$ formulering wat myns insiens ook vir die Van den Berg-diskoers geld:

The written word of God is not to be mistaken for the living Word of God and the realities of life in God. Nevertheless, it shares a miraculous sacramental connection to that reality and is able to represent and actualize it as we engage with the written text. I believe the whole text is relevant to the whole salvation history reality and nature of God, which it is meant to represent. While absolute inerrancy is not required, one cannot ignore or rewrite significant themes and narratives that are part of its essential fabric without radically distorting it and consequently damaging the experience of the life of God that it is meant to represent and actualize. (p. 292)

Hier is die unieke aard van die Skrif normatief. Die doel waartoe die Heilige Gees die Skrif gegee het, is die rigtinggewende aanduiding van die toepassing daarvan in die pastorale konteks.

Crabb (1987:21-44) laat die Skrif in sy ontwerp vir 'n pastorale model leidinggewend meewerk. Die Skrif dui 'n duidelike rigting aan deur elke denkbare lewensvraagstuk in verhouding met Christus te plaas. Louw bly ook aan sy teologiese (dogmatiese) fundering in sy vroeëre werk (1997) getrou. In 'n indringende bespreking oor menslike seksualiteit word die seksuele byvoorbeeld onlosmaaklik aan teologiese grondmotiewe verbind soos die menswording van Christus, eskatologie en pneumatologie, terwyl hierdie temas aan 'n weldeurdagte teologiese antropologie verbind word. Hy maak 'n keuse vir 'n pneumatologiese en inwonende model. Dit beteken: '(T)he status of our being human in terms of the indwelling presence of God in our human bodies; our bodies as containers of the charisma and fruit of the Spirit' (Louw 2009:97). Die Skrif speel in hierdie basisteorie kennelik 'n belangrike rol. Dit moet as eerste vereiste vir 'n reformatoriese pastoraat beskou word.

\section{God as primêre subjek}

Die hermeneutiese intersubjektiewe benadering wat deesdae normatief vir die pastoraat geword het, behoort met 'n subjek-objekbenadering afgewissel te word sodat God as die primêre subjek van die pastoraat tereg kan kom. Vir Firet is die 'praxis Gottes' steeds belangrik. Daiber (1977:9-23) wil egter die praxis Gottes met die praksis van die gemeente vervang. In die prakties-teologiese epistemologie word die kommunikatiewe handelings van die gemeente dan die uitgangspunt, terwyl dogmatiese leerstellings nie toegelaat word om oor die praktiese teologie te heers nie. Daarom behandel Daiber die praktiese teologie as 'n onderafdeling van die handelingswetenskaplike teorie (Daiber 1977:9-23, 206-219). Pieterse (1994:93-100) volg dieselfde uitgangspunt deur die praktiese teologie as die kommunikatiewe handelingsteorieë oor God te definieer.

Die afwesigheid van teologiese (dogmatiese) grondmotiewe in prakties-teologiese navorsing word duidelik deur die kontemporêre postmoderne vakliteratuur gereflekteer. Die God-is-dood-teologie (Nietzsche) en die dood-van-die-subjek (postmoderne slagspreuk) ontmoet mekaar in die dood van God as subjek (Janse van Rensburg 2000a:8-9). God is nie langer die objek soos wat dit in die bybelse konteks ter sprake kom nie, maar Hy is ook nie die subjek van die pastorale teologie nie. God is dood; dood is God (Breech 1989:15). Hoewel dit nie beteken dat dit' $n$ algemene vertrekpunt in die praktiese teologie is nie, is dit die onafwendbare gevolg van 'n postmoderne epistemologie - die relativering van enige objektiewe waarheid. Immers, God kan nie die subjek van die pastoraat wees indien God nie 'n absolute werklikheid is nie. Bohren (1975:124) het vroegtydig 'n waarskuwing laat hoor dat die teorie van kommunikatiewe handelinge die praxis Gottes sal relativeer.

'n Trinitariese benadering tot die pastoraat en die pastorale teologie kom wél hier en daar as moontlikheid na vore (Van 
Pelt 1999). Maar kan 'n trinitariese vertrekpunt weer in die pastorale teologie 'n plek kry? 'n Trinitariese vertrekpunt impliseer noodwendig dat God as die subjek van die pastoraat in ere herstel word. Die Vader stuur immers sy Seun om te soek en te red wat verlore is. Jesus is die goeie Herder wat sy lewe vir sy skape aflê sodat hulle 'n lewe in oorvloed kan hê (Joh 10). Die pastor is nie net 'n kliniese berader nie en die persoon in berading is nie net ' $n$ kliënt nie. Die herdermetafoor is dus 'n onlosmaaklike deel van 'n reformatoriese pastoraat. Daarvolgens werk die Heilige Gees kragtig in die pastorale gesprek mee.

Die metafoor van dans is 'n tipiese postmoderne simbool van interaksie. Binau (2014:11) gebruik egter juis hierdie metafoor in sy oproep om na 'n trinitariese benadering tot die ekklesiologie en die pastoraat terug te keer. Hy vra vir 'n herontdekking van die wonder en krag van 'n trinitariese vertrekpunt. Inspirerend is die aanhef tot sy artikel (Binau 2014):

Come, join the dance of Trinity, before all worlds begun the interweaving of the Three, the Father, Spirit, Son.

The universe of space and time did not arise by chance,

but as the Three, in love and hope, made room within their dance. (p. 11)

Dit is egter belangrik om Binau (2014) se beskrywing van die trinitariese teologie te verstaan. Dit gaan vir hom nie om die ontiese interpretasie van God se wese nie, maar eerder om:

... a teaching about God's life with us and our life with each other. Trinitarian theology could be described as par excellence a theology of relationship, which explores the mysteries of love, relationship, personhood and communion within the framework of God's self-revelation in the person of Christ and the activity of the Spirit. (p. 16)

Dit gaan vir hom om die sosiale dimensie van God se triniteit, naamlik sy missio dei [interaksie] om nie net die cura animarum te fasiliteer nie, maar ook om die samelewing waarin die individu worstel om te bestaan, te modifiseer en sodoende 'n nuwe hemel en aarde te skep (Binau 2014:18). As sodanig verteenwoordig dit ' $n$ holistiese benadering tot die pastoraat (Janse van Rensburg 2010).

Tereg sê Venter (2010:567) dat dit die heel basiese beginsel vir 'n trinitariese teologie verteenwoordig om só oor die handelende God te praat. Die belang van Venter se betoog vir 'n trinitariese teologie, wat besondere waarde aan die pastorale teologie toevoeg, is dat hy die triniteit in verband met verbeelding as 'imaginative construction' bring (Venter 2010:574). Toegepas op die pastorale teologie beteken dit dat ' $n$ trinitariese pastoraat in kreatiwiteit en verskeidenheid gedoen word, omdat daar by God onbeperkte moontlikhede is (vgl. ook die teologiese uitkoms teenoor die antroposentriese uitkoms van die postmoderne narratiewe terapie hieronder). Waar die dogmatiek egter nie toegelaat word om in 'n vennootskap met die pastorale teologie te tree nie en religieuse grondmotiewe as gevolg van ' $n$ postmoderne epistemologie uitgerangeer word, sal hierdie verryking van die pastoraat nie maklik plaasvind nie. Terwyl ' $\mathrm{n}$ trinitariese pastoraat van bo is, is die konstruktivistiese en nie-direktiewe narratiewe terapie kennelik van onder. Alhoewel die werking en leiding van die Heilige Gees in die pastorale gesprek 'n inwendige (subjektiewe) werking het (die sg. inhabitasie van die Gees), bly dit primêr 'n werking van Bo omdat die pastorale handeling nooit volledig in die pneumatologiese werking opgaan nie. Van Heerden en Kotzé (1997:84-92), wat self verkies om 'n postmoderne epistemologie te volg, kom later tot die gevolgtrekking dat hierdie epistemologie in sy uiterste konsekwensie niks anders as humanisme is nie.

God moet dus die primêre subjek van die pastoraat en pastorale teologie bly. Dit beteken nie slegs dat die Skrif namens God moet spreek nie. Dit sou te meganies wees. God as die subjek is egter dinamies en interaktief in die pastorale proses en daarom behoort die term praxis Gottes voorkeur te geniet. De Freitas (2012) wys ook daarop dat 'n trinitariese benadering nie net in die direkte Skrifgebruik opgaan nie.

It involves being led by the Holy Spirit to speak and act the truth and love of the Trinity as revealed directly by the Trinity in conjunction with the Bible ... In a similar way one may be led to operate without the written Scriptures in a specific session, but a genuine engagement with the Trinity will ultimately lead to a profound interaction with the written Scriptures both within and outside of the pastoral care session. (pp. 278-279)

\section{Die verbond as normatief}

Die verbond as grondbeginsel van 'n reformatoriese benadering behoort sterker te figureer. By De Klerk (1985:21, 31-39) vervul die subtemas van verbondstrou, verbondsbreuk en verbondsherstel 'n belangrike rol in die pastorale gesprek. Inhoudelik weerspieël dit die aktivering van geloof en bekering, terwyl die verbondswet die kader is waarbinne die verbond in die pastoraat figureer (De Klerk 1985:23-28). Dit val onmiddellik op hoe radikaal hierdie beskouing van die konstruktivistiese narratiewe benadering verskil - die beskouing van die konstruktivistiese narratiewe benadering om nie-direktief en met 'n eie unieke uitkomste te werk.

Vir Maree en Janse van Rensburg (2009:173) is die pastoraat uitnemend geskik om God se verbondsboodskap van Jesus Christus se vleeswording te kommunikeer. Die pastor moet die verbondskommunikator wees om al die bedieningsfasette te betrek. Dit gaan dus nie net oor paraklese nie, maar ook oor didache, kerugma en koinonia.

In 'n postmoderne benadering waar die rol van die dogmatiek ontken en deur die beginsel van verhoudings vervang word, kry leerstellige grondmotiewe en etiese normering soos die verbond geen plek of erkenning nie. Indien die pastoraat reformatories moet restoureer, sal die verbond sonder twyfel weer in die pastoraat tereg moet kom. Aangesien die verbond en die uitverkiesing twee 
fundamentele grondbeginsels van die koninkryk is (Heyns 1978:223), funksioneer die verbond as 'n goue draad wat deur elke bybelse tema geweef is. Die koninkryk, pneumatologie, kerugma en eskatologie kan nie sonder die verbond verstaan word nie (Janse van Rensburg 1996:152-165). Die herstel van die verbond in die pastoraat beteken egter nie dat dit totaal onversoenbaar met kontemporêre benaderings is nie. Dit is byvoorbeeld ironies dat die verbond juis 'n dogma van verhoudings is, terwyl Dill en Kotzé (1997:23) die pastoraat in verhoudings laat opgaan. Waar die Skrif as die etiese norm by die konstruktivisme ten koste van verhoudings losgelaat word, kan 'n korrekte verstaan van die verbondsperspektief help om aan die pastorale verhoudings 'n dieper dimensie te verleen.

Louw (2002:90-97) wil juis die verbond as 'covenantal schema of interpretation' gebruik om na 'n trans-postmoderniteit te kan beweeg. Daarmee bedoel hy die betroubare teenwoordigheid en vriendskap van God. In so 'n benadering word die teodisee en die oordele van reg en verkeerd deur God se liefde vervang. Sy gevolgtrekking is betekenisvol:

If trans-postmodernity is indeed a realistic supplement to postmodernity, theology should respond with a spirituality 'beyond' legalities, concentrating on the essential message of covenantal grace, as well as the most fundamental issues in on being the church: the encounter between humans as established in fellowship. (Louw 2002:95).

Hoewel Louw se perspektiewe en gebruik van die verbond uiters belangrik is, moet die vraag tog gestel word of dit hier oor 'n reformatoriese verstaan van die verbond gaan. God se verbond in die Ou Testament, ook bevestig in die NuweTestamentiese verbond, is tog nie net liefde en genade nie. Deur legalities te vermy, word die verbondswet as essensiële uitdrukking van die liefde uitgeskakel. Indien alles tot verhoudings (fellowship) gereduseer word, is 'n mens nie maar in wese terug by die konstruktivistiese verstaan van 'n pastorale gesprek nie? Indien wel, is 'n mens nie meer by trans-postmodernisme soos Louw voorstel nie, maar juis terug by die postmoderne sosiale konstruksionisme waar verhoudings belangriker as etiese norme is. Die handhaaf en opdring van etiese beginsels en ewige waarhede word immers in ' $n$ postmoderne epistemologie as ' $n$ magspel beskou. Volgens Lyotard (1993:261) behoort mag aan geen individu nie en mag setel ook in geen sisteem nie. Dill en Kotzé (1997:23) laat die uiteensetting van 'n nuwe epistemologie vir die praktiese teologie en pastorale terapie in die uitgangspunt opgaan dat morele gesag nie meer buite die mens (dus ook nie in God of die Skrif of die pastor) gesetel is nie, maar in die verhoudings waarin die mens staan.

Delkeskamp-Hayes (2010:80-82) verwys na 'n ander paradigmaskuif, naamlik van 'n tradisionele Christelike (skrifgefundeerde) pastoraat na 'n psigoanalitiese pastoraat. In hierdie modernistiese benadering word etiese normering prysgegee (reconfigured) ter wille van die psigoanalitiese hantering van etiese vraagstukke soos aborsie en seksualiteit. Paraklese versand in die bedding van psigoterapeutiese en nie-veroordelende akkommodasie. Onder die studieleiding van prof. G.A. Lotter identifiseer A.P. Bezuidenhout (2005) vier erkende paradigmas in die psigologie. Die lewe en leer van die vier hooffigure bewys dat hulle bogemiddelde blootstelling aan die Skrif gehad het, maar die Skrif is telkens ten koste van geloof in die sielkunde agtergelaat.

Delkeskamp-Hayes (2010:87-91) poog om hierdie dialektiek op te los. Die pastor is kragtens sy pastorale syn en kundigheid met gesag beklee. Psigoterapeutiese insigte word deur die pastor se nie-veroordelende houding bestuur wat die ruimte skep waarbinne die persoon in berading aangemoedig kan word om met vertroue openhartig te wees. Die gesag van die pastor is nie oorheersend nie omdat sowel die pastor as die persoon in berading sondaars voor God is.

Hierdie benadering is nie in alle opsigte bevredigend nie. Dit ontkom nie die feit dat 'n egte psigoterapeutiese paradigma nie aan geloofsmatige vertrekpunte (bv. die mens as sondaar) erkenning gee nie. Sodanige benadering beweeg dan beurtelings tussen geloof en sielkunde. Die grootste probleem lê egter daarin dat die uiteensetting van die versoeningsmodel tussen epistemologieë nie konsekwent blyk te wees nie. 'n Mens kry die indruk dat Delkeskamp-Hayes aan Skrifwaarhede wil vashou en aan die pastor 'n direktiewe maar nie-veroordelende aksie toeken. Maar dan stel hy (2010) weer dat pastorale terapie beskryf kan word:

... as enabling parishioners to pursue their very own, noninterchangeable and personally endorsed way of growing in the faith. Such growth, along with a person's divinely intended self-realization, presupposes that what impedes his freedom has been removed (p. 90).

Daar is myns insiens 'n baie geringe onderskeid tussen hierdie selfrealiserende benadering en die unieke-uitkomsmetodiek van die konstruktivisme. Deur wie en volgens watter normering word die 'divinely intended self-realization' byvoorbeeld bepaal? Wanneer is die selfrealisering werklik van goddelike oorsprong? Daarbenewens kan die verwydering van hindernisse op weg na vryheid in die ideaal van selfrealisering juis in die teenoorgestelde rigting as die goddelike bedoeling loop.

By 'n verbondmatige pastoraat is dit egter anders. Paraklese is so 'n wesenlike deel van 'n verbondspastoraat (De Klerk 1985:23) dat dit ondenkbaar is om dit uit 'n reformatoriese pastorale benadering weg te laat. Natuurlik impliseer dit hoegenaamd nie 'n onpersoonlike en rigiede toepassing van norme nie. Indien die verbond in bybelse perspektief hoofsaaklik oor verhoudings gaan, spreek dit vanself dat etiese normering en vermaning slegs in 'n pastorale verhouding en met 'n pastorale gesindheid mag geskied. Daarbenewens meen Osmer (2008:58) ook tereg dat dit nie so eenvoudig is om feite deur waarneming vas te stel nie. 
Pastors moet dus uiters versigtig wees om nie hulle eie waarnemings ten opsigte van 'n krisis normatief te maak en oorhaastig of onoordeelkundig met raadgewing, vermaning of oordeel te kom nie. 'n Eksklusiewe en eensydige subjekobjekbenadering moet daarom vermy word. Die pastor wat met 'n pastorale grondhouding van liefde werk wat dien, aanvaar, offer en respekteer, sal met groot empatie en omsigtigheid enige gesprek oor etiese normering binne die veilige ruimte van 'n pastorale verhouding hanteer.

Die waarde van Browning $(1983: 11,15)$ se praktiese morele rasionaal is juis daarin geleë dat die morele begeleiding in die pastorale konteks verantwoordelik moet wees. Noukeurige navraag oor die aard van die morele probleem en die individuele en sosiale konteks bemagtig die pastor om informatiewe leiding te gee. Dit verteenwoordig 'n holisties-analitiese benadering wat vanuit 'n evaluering van die persoon in berading se individuele en sosiale konteks vertrek. Hierin wil Browning die psigoterapie as vennoot gebruik aangesien pastorale teologie en psigoterapie oor 'n gemeenskaplike terminologie beskik. Omdat die pastor 'n strategies belangrike funksie in die pastoraat vervul, moet hierdie verantwoordelikheid tot elke prys teen die negatiewe invloed van die Modernisme beskerm word.

Dit is egter tegelyk hartseer en ironies dat Browning se insiggewende uitgangspunte juis deur die Modernisme geneutraliseer word. Browning wil die psigoterapie as vennoot gebruik, terwyl psigoterapie 'n modernistiese benadering verteenwoordig omdat dit met vaste diagnoses en prognoses werk - iets wat in 'n postmoderne benadering juis as die etiketering van die kliënt beskou word. Die klem op psigoterapeutiese metodes het weer 'n selfvernietigende kiem soos die spreekwoordelike Trojaanse perd in die pastoraat ingedra. Waar die unieke eie-aard van die pastoraat en die psigoterapie nie as onderskeie professionele velde gehandhaaf is nie en ongekwalifiseerde pastors in psigoterapeutiese metodes begin eksperimenteer het, het die psigoterapie in die praktyk so begin oorheers dat die pastorale aard deur psigoterapie vervang is. Browning was deeglik van hierdie gevaar bewus. Sy vrees dat die pastorale sorg in normlose psigoterapie sou ontaard (Browning 1983:16-20) is bewaarheid, nie alleen deur oorname deur die psigoterapie nie, maar ook deur die postmoderne narratiewe terapie met sy nie-diagnostiese en nie-direktiewe selfrealiserende benadering.

Indien die verbond reg verstaan en toegepas word, bied dit juis die veilige ruimte waarbinne die pastorale identiteit gehandhaaf en beskerm word, sodat paraklese helend kan funksioneer. Selfs wanneer vermaning (nouthetein) nodig word, sal die pyn van so 'n ervaring in die pastorale situasie deur verbondsliefde en liefdevolle verhoudings getemper word. Sodoende word die volle reikwydte van die parakletiese verantwoordelikheid van die pastor, wanneer nodig, nie ontduik, vermy of vervorm nie.

\section{God se unieke uitkoms}

Die uiteensetting van die paradigmaskuif van 'n diakoniologiese na 'n prakties-teologiese en postmoderne (konstruktivistiese) epistemologie in die pastorale teologie het laat blyk hoe die nie-direktiewe benadering en die kliënt as die spesialis die dominante model vir die pastoraat geword het. Dit mag nie ontken word dat hierdie metode meriete het nie. By 'n eensydige subjek-objekbenadering kan die pastorale gesprek skeefloop omdat die pastor sy eie analise en oplossing van die probleem aan die persoon in berading opdring. ' $n$ Nie-direktiewe benadering mag egter ook nie verabsoluteer word nie. Waar dit gebeur, word die kliënt se eie unieke uitkoms normatief en moet pastors hulle daarvan weerhou om daardie uitkoms te korrigeer of om die persoon te probeer verander. Daarenteen meen Capps (1988:53-54) dat die Skrif oor die inherente vermoë beskik om persepsies, gedrag en houdings te verander. Hierdeur kom paraklese en bekering in 'n reformatoriese pastoraat tereg, sonder dat die gesprek noodwendig in 'n kerugmatiese oproep tot bekering opgaan. 'n Unieke uitkoms, wat by die narratiewe benadering sterk figureer, behoort met God se unieke uitkoms as uiteindelike doelwit van die pastorale proses gekoppel te word. Dit is waarskynlik hier waar 'n pneumatologiese persepktief in 'n pastorale epistemologie waardevol kan wees

Bruinsma-de Beer (2006:172) kom naby hieraan wanneer sy by die pastorale teologie van Henning Luther (1992) aansluit. Sy vereenselwig haar met $\mathrm{H}$. Luther se keuse vir 'n geïndividualiseerde godsdiensbenadering teenoor die psigososiale wetenskaplike benadering van die Sielkunde. Haar benadering impliseer dat die pastorale sorg (nie hulp nie, n.a.v. Heitink 1998:13-14 se onderskeid) in dié opsig uniek is dat die geloof en godsdiens die vertrekpunt word van waar nuwe moontlikhede vir die persoon in berading oopgebreek word. Bruinsma-de Beer (2006) skryf:

This possibility is very unique. Ordinary life opens up for the transcendent reality of God. People may experience that 'it could be otherwise' ... This experience opens 'a search for significance in ways related to the sacred'. (p. 172)

Teenoor die sielkunde wat mense enersyds in die diagnose van 'n patologie vasvang, en die eie unieke uitkoms van die postmoderne narratiewe terapie andersyds, bied 'n Godgefundeerde benadering die moontlikheid van verandering, vernuwing, bevryding en hoop. God is immers in staat om veel meer te doen as wat ons kan bid of dink (Ef 3:20).

\section{Samevattende evaluering}

In watter mate kan bogenoemde eienskappe van 'n reformatoriese pastoraat (ander kan ook geïdentifiseer word) in die huidige stand van pastorale teologie teruggevind word? Watter hoop is daar dat daar' $n$ terugkeer na 'n reformatoriese benadering tot die pastorale teologie sal wees? Reese (2006:37) bevind dat die protestantse meerderheid in Amerika 'n 
duidelike afname toon. In die Suid-Afrikaanse konteks blyk dit ook die stand van sake te wees. Reflekteer dit bepalend op die moontlikheid om ' $n$ reformatoriese benadering tot die pastoraat hervestig te kry? Is daar verder ook 'n onderskeid tussen die akademiese besinning oor die pastoraat en die uitvoering van 'n pastorale bediening op grondvlak? Ly die pastoraat nie dalk tans aan 'n skadelike eensydigheid nie - 'n bybelse benadering sonder wetenskaplike insigte of ' $n$ suiwer kliniese benadering waarin daar weinig van ' $n$ pastorale houding en proses teregkom? Is daar 'n weg tussen modernistiese en postmoderne epistemologieë? Is daar hoop dat 'n mens uit die greep van modernistiese sekularisme en postmoderne relativisme bevry kan word om eendag weer van 'n reformatoriese pastoraat en pastorale teologie te kan praat?

\section{Erkenning Mededingende belange}

Die outeur verklaar dat hy geen finansiële of persoonlike verbintenis het met enige party wat hom nadelig kon beïnvloed in die skryf van hierdie artikel nie.

\section{Literatuurverwysings}

Anderson, H. \& Goolishian, H., 1992, 'The client is the expert: A not-knowing approach to therapy', in S. McNamee \& K.J. Gergen (eds.), Therapy as social construction, pp. 25-39, Sage, London.

Bezuidenhout, A.P., 2005, 'Die klaarblyklike onversoenlikheid tussen die gereformeerde pastoraat en die moderne sekulêre psigologie: 'n Praktiesteologiese studie', HonsBA (Theologia)-skripsie, Fakulteit Teologie, NoordwesUniversiteit. (Ongepubliseer).

Bingaman, K.A., 2013, 'The promise of neuroplasticity for pastoral care and counseling', Pastoral Psychology 62(5), 549-560. http://dx.doi.org/10.1007/ s11089-013-0513-0

Binau, B.A., 2014, 'Pastoral theology for the missional church: From pastoral care to the care of souls', Trinity Seminary Review 34(1), 11-28.

Bohren, R., 1975, Dass Gott schön werde: Praktische Theologie als theologische Astetik, Kaiser Verlag, München.

Bolkestein, M.H., 1964, Zielszorg in het Nieuwe Testament, Keulen, Den Haag.

Breech, J., 1989, Jesus and Postmodernism, Fortress, Minneapolis.

Browning, D., 1983, Religious ethics and pastoral care, Fortress, Philadelphia.

Bruinsma-de Beer, J., 2006, 'The subject of pastoral care: A discussion based on the theology of Henning Luther', Pastoral Psychology 55(2), 167-174. http://dx.doi. org/10.1007/s11089-006-0043-0

Burnell, B.M., Beukes, R.B.I. \& Esterhuyse, K.G.F., 2009, 'The relationship between spiritual well-being and a sense of meaning in life in late adolescence', Praktiese Teologie in Suid-Afrika 24(1), 1-31.

Capps, D., 1988, 'The Bible's role in pastoral care and counseling: Four basic principles', in L. Aden \& J.H. Ellens (eds.), The church and pastoral care, pp. 41-55, Baker, Grand Rapids.

Crabb, L., 1987, Understanding people: Reaching deeper through biblical counseling, Harper Collins, London.

Daiber, K-F., 1977, Grundriss der Praktischen Theologie als Handlungswissenschaft: Kritik und Erneuerung der Kirche als Aufgabe, Kaiser Verlag, Grünewald.

De Freitas, T.M., 2012, 'Epistemology and the use of Scripture in pastoral care and counseling', D.Th. thesis, Faculty of Theology, University of Stellenbosch. (Unpublished).

De Klerk, J.J., 1985, Verbond en bediening, NG Kerkuitgewers, Kaapstad.

De Wet, F.W. \& Pieterse, H.J.C., 2010, 'Die noodsaak van die verkenning van metateoretiese vertrekpunte in prakties-teologiese wetenskapsbeoefening', In die Skriflig 44(3\&4), 525-544.

Delkeskamp-Hayes, C., 2010, 'Psychologically informed pastoral care: How serious can it get about God?', Orthodox reflections on Christian counseling 16(1), 79-116.

Dill, J., 1996, "n Basisteorie vir pastorale terapie in die lig van post-moderne epistemologie' PhD-proefskrif, Universiteit van die Vrystaat. (Ongepubliseerd).

Dill, J. \& Kotzé, D.J., 1997, 'Verkenning van 'n postmoderne epistemologiese konteks vir die Praktiese Teologie', Acta Theologica 17(1), 1-23.
Firet, J., 1977, Het agogisch moment in het pastorale optrede, Kok, Kampen.

Firet, J., 1986, Dynamics in pastoring, Eerdmans, Grand Rapids.

Fowler, G., 2012, 'The ministry of care in twenty-first-century protestant congregations', Pastoral Psychology 61(2), 197-210. http://dx.doi.org/10.1007/ s11089-011-0425-9

Heitink, G., 1993, Practische Theologie: Geschiedenis, theorie, handelingsvelden, Kok, Kampen.

Heitink, G., 1998, Pastorale zorg: Theologie, differentiatie, praktijk, Kok, Kampen.

Heyns, J.A., 1978, Dogmatiek, NG Kerkboekhandel, Pretoria.

Heyns, J.A. \& Jonker, W.D., 1977, Op weg met die teologie, NG Kerkboekhandel, Pretoria.

Janse van Rensburg, J., 1996, Verbond en pastoraat, Nederduitse Gereformeerde Teologiese Tydskrif (NGTT) 27(1), 152-165.

Janse van Rensburg, J., 2000a, The paradigm shift: An introduction to postmodern thought and its implications for theology, Van Schaik, Pretoria.

Janse van Rensburg, J., 2000b, The subject of pastoral care: An epistemological discourse, Kaleidoskoop, Bloemfontein. (Acta Theologica, Supplementum 1, 1-25).

Janse van Rensburg, J., 2004, Speel die Bybel nog ' $n$ rol in die praktiese teologie? Acto Theologica, Supplementum 6, 36-37.

Janse van Rensburg, J., 2007, 'Voortsetting van die epistemologiese diskoers in die praktiese teologie: In gesprek met J-A van den Berg', Praktiese Teologie in SuidAfrika 22(2), 61-80.

Janse van Rensburg, J., 2010, 'A holistic approach to pastoral care and poverty', Verbum et Ecclesia 31(1), Art. \#386, 7 pages.

Johnson, B. \& Christensen, L., 2008, Educational research: Quantitative, qualitative and mixed approaches, 3rd edn., Sage, London.

Jossitus, M., 1980, Praxis des Evangeliums zwischen Politik und Religion, Kaiser Verlag, München.

Joubert, B.F., 2000, 'The social koinonial construction of pastoral therapy in clergy training', PhD Thesis, Faculty of Theology, University of the Free State. (Unpublished).

Kotzé, E. \& Kotzé, D.J., 1997, 'Social construction as a postmodern discourse: An epistemology for conversational therapeutic practice', Acta Theologica 17(1), 27-50.

Lotter, G.A., 2001, 'The "reformation" of counselling', In die Skriflig 35(2), 317-329. http://dx.doi.org/10.4102/ids.v35i2.562

Louw, D.J., 1993a, 'Praktiese Teologie - 'n Fenomenologiese stuiptrekking?' Praktiese Teologie in Suid-Afrika 8(2), 206-209.

Louw, D.J., 1993b, 'Kroniek: Praktiese teologie/pastoraat/gemeentebediening', Praktiese Teologie in Suid-Afrika 8(2), 193-196.

Louw, D.J., 1997, Pastoraat as vertolking en ontmoeting, Lux Verbi, Kaapstad.

Louw, D.J., 1998, 'Hoe teologies is die praktiese teologie en hoe prakties is die teologie? Ontwerp vir'n prakties-teologiese hermeneutiek', Praktiese Teologie in Suid-Afrika 13(1), 43-63.

Louw, D.J., 2002, 'Nightmare after the American dream - Reassessing paradigms and possible leap into "Trans-Postmodernity"'? Praktiese Teologie in Suid-Afrika 17(2), 75-97.

Louw, D.J., 2003, 'The paradigmatic revolution in practical and pastoral theology: From metaphysics (substantial thinking) to empirism (experential thinking); From theism to theopaschitism (hermeneutical thinking), Praktiese Teologie in SuidAfrika 18(2), 33-58.

Louw, D.J., 2009, 'Human sexuality in an eschatological perspective: Towards an aesthetics of human embodiment and erotic sensuality in practical theology', Praktiese Teologie in Suid-Afrika 24(1), 89-114.

Luther, H., 1992, Religion und Alltag: Bausteine zu einer praktischen Theologie des Subjekts, Radius-Verlag, Stuttgart.

Lyotard, J-F., 1993, Libidinal economy, transl. lain Hamilton Grant, Athlone Press, London.

Maree, D. \& Janse van Rensburg, J., 2009, 'Pastorale sorg aan gemarginaliseerdes met spesifieke verwysing na kinderhuiskinders', In die Skriflig 43(1), 159-180. http:// dx.doi.org/10.4102/ids.v43i1.219

Maturana, H., 1985, 'An interview with Humberto Maturana', Networker May/June, 36-43.

Meylahn, J-A., 2010, 'Holistic redemptive pastoral ministry in the fragmented transit hall of existence', Hervormde Teologiese Studies 66(1), 1-9. http://dx.doi. org/10.4102/hts.v66i1.426

Osmer, R.R., 2008, Practical Theology: An introduction, Eerdmans, Grand Rapids.

Pieterse, H.J.C., 1994, 'Metateorie as wetenskapsbenadering in die praktiese teologie', Praktiese Teologie in Suid-Afrika 8(2), 93-100.

Pieterse, H.J.C., 2010, 'Grounded theory approach in sermon analysis of sermons on poverty and directed at the poor as listeners', Acta Theologica 30(2), 113-129.

Raath, A.W.G., 1998, 'Dialektiek van die Verligting', Tydskrif vir Christelike Wetenskap, spesiale uitgawe April, 127-158.

Reagen, C.F. \& Stewart, D. (eds.), The philosophy of Paul Ricoeur: An anthology of his work, Beacon, Boston.

Rebel, J.J., 1981, Pastoraat in pneumatologisch perspektief, Kok, Kampen. 
Reese, M.G., 2006, Unbinding the gospel: Real life evangelism, Chalice, St. Louis.

Ricoeur, P., 1973, 'The critique of religion', Union Seminary Quarterly Review 28(3), 203-212.

Rorty, R., 1989, Contingency, irony, and solidarity, Cambridge University Press, Cambridge. http://dx.doi.org/10.1017/CBO9780511804397

Roux, J.P. \& Kotzé, D.J., 1997, 'Die koinoniale konstruksie van 'n toerustingsprogram vir die narratiewe pastorale sorg', Acta Theologica 17(1), 51-80.

Seidman, S., 1994, Contested knowledge: Social theory in the postmodern era, Blackwell, Oxford.
Van den Berg, J-A., 2006, "n Verandering in tongval ...? 'n Verwoord(-beelding) van pastoraal-teologiese perspektiewe', Praktiese Teologie in Suid-Afrika 21(2), 164181.

Van Heerden, P.R. \& Kotzé, D.J., 1997, 'Die pastorale gesprek binne 'n narratiewe diakonale pastoraat', Acta Theologica 17(1), 81-98.

Van Knippenberg, T., 2002, 'Sources of spiritual guidance: An exercise in the cure of souls', Praktiese Teologie in Suid-Afrika 17(2), 154-169.

Van Pelt, J.W., 1999, Pastoraat in trinitarisch perspectief, Groen, Heerenveen.

Venter, R., 2010, 'Doing trinitarian theology: Primary references to God and imagination', In die Skriflig 44(3\&4), 565-580. 